\title{
EVALUASI LEMBAGA KEBERATAN DALAM PENYELESAIAN SENGKETA PAJAK YANG ADIL DI DIREKTORAT JENDERAL PAJAK
}

Supriyadi

Politeknik Keuangan Negara STAN

Beny Setiawan

Politeknik Keuangan Negara STAN

Randy Matius Bintang

Direktorat Jenderal Pajak

Alamat Korespondsi : priesoekarno@gmail.com

\section{INFORMASI ARTIKEL}

Diterima Pertama

4 September 2019

Dinyatakan Diterima

1 Desember 2019

KATA KUNCl:

Lembaga Keberatan, Sengketa Pajak, Adil dan Direktorat Jenderal Pajak

KLASIFIKASI JEL:

$\mathrm{H} 2 \mathrm{O}$

\section{ABSTRACT}

One of the legal efforts that can be taken by taxpayers in the event of a tax dispute by submitting an objection to the objection institution located at the Directorate General of Taxes. This objection is essentially a legal effort outside the Tax Court to ask for justice in a tax dispute. The problem is there are some weaknesses related to justice towards the objection institution in processing the existing objections, namely: psychological pressure on objector reviewers, non-independent organizational structure, resource management, especially the Objection Review Team, which is not yet optimal.

To overcome these problems, there are several strategies to improve the quality of the objection process, namely: the objector reviewers are given legal protection guarantees, changes in institutional structure to increase the independence and objectivity of the objector reviewers, the functionalization of the objector reviewers and the provision of education and training related to handling objections.

\section{ABSTRAK}

Upaya hukum yang dapat ditempuh wajib pajak dalam hal terjadi sengketa pajak dengan mengajukan keberatan kepada lembaga keberatan yang berada di Direktorat Jenderal Pajak. Keberatan ini pada hakikatnya merupakan upaya hukum yang berada diluar Pengadilan Pajak untuk memohon keadilan dalam sengketa pajak. Permasalahanya terdapat beberapa kelemahan terkait keadilan terhadap lembaga keberatan dalam memproses keberatan yang ada saat ini, yaitu: adanya tekanan psikologis pada penelaah keberatan, struktur organisasi yang tidak independen, manajemen sumber daya manusia khususnya para Tim Penelaah Keberatan yang belum belum optimal.

Untuk mengatasi permasalahan tersebut terdapat beberapa startegi untuk meningkatkan kualitas proses keberatan, yaitu: penelaah keberatan diberikan jaminan perlindungan hukum, perubahan struktur kelembagaan untuk meningkatkan independensi dan objektivtas penelaah keberatan, fungsionalisasi penelaah keberatan dan pemberiaan Pendidikan dan pelatihan terkait penanganan keberatan. 


\section{PENDAHULUAN}

\subsection{Latar Belakang}

Mulai tahun 1984 sistem perpajakan di Indonesia menganut prinsip self assessment system, Wajib Pajak diberikan kewenangan untuk menghitung, menyetor dan melaporkan kewajiban perpajakannya. Negara, melalui Direktorat Jenderal Pajak melakukan fungsi penyuluhan, pelayanan, pengawasan dan upaya penegakan hukum kepada para Wajib Pajak.

Upaya penegakan hukum yang dilakukan Direktorat Jenderal Pajak (DJP) salah satunya melalui pemeriksaan. Pemeriksaan adalah suatu proses yang bertujuan untuk menguji kepatuhan pemenuhan kewajiban perpajakan dan/atau tujuan lain sesuai peraturan undang-undang Perpajakan. Melalui pemeriksaan ini Direktorat Jenderal Pajak akan menetapkan besarnya pajak yang terutang yang harus dibayar oleh Wajib Pajak dengan produk berupa surat ketetapan pajak (skp). Perhitungan dalam skp ini sering tidak sesuai dengan perhitungan Wajib Pajak yang akan menimbulkan sengketa pajak.

Di Indonesia penyelesaian sengketa pajak surat ketetapan pajak dapat diselesaikan melalui keberatan. Permohonan keberatan diajukan oleh Wajib Pajak diajukan dan diproses di DJP. Dalam penyelesaian keberatan ini DJP sering disebut peradilan semu (Soemitro, 1991).

Proses Keberatan memberikan kesempatan pada wajib pajak untuk tidak menyetujui jumlah angka yang ditetapkan oleh pemeriksa pajak apabila mereka tidak puas atas hasil tersebut, dan memiliki dasar dan bukti yang kuat atas perhitungan mereka. Kesempatan ini mencerminkan asas keadilan yang dipegang oleh pemerintah atas setiap perbedaan jumlah pajak terutang yang dihitung oleh kedua belah pihak.

Namun pada praktiknya, proses Keberatan dianggap berat sebelah oleh para wajib pajak. Hal ini ditunjukkan oleh banyaknya permohonan keberatan yang ditolak oleh DJP. Mayoritas penyelesaian keberatan berujung pada penolakan seluruhnya dan menerima sebagian permohonan. Persentase hasil keberatan dapat dilihat pada Tabel 1.1. Selama 4 tahun terakhir, keputusan yang menolak keberatan selalu berada di atas angka 70\% per tahunnya. Sedangkan keputusan untuk mengabulkan sebagian permohonan Keberatan WP berada di posisi tertinggi kedua, yakni $13,27 \%$ secara total 4 tahun.

Tabel 1.1 Hasil Keputusan Keberatan

\begin{tabular}{|c|c|c|c|c|c|}
\hline \multirow{2}{*}{$\begin{array}{l}\text { Tahun } \\
\text { Keputusan }\end{array}$} & \multicolumn{5}{|c|}{ Jenis Keputusan Keberatan } \\
\hline & $\begin{array}{l}\text { MENGABULKAN } \\
\text { SELURUHMYA }\end{array}$ & MENOLAK. & $\begin{array}{l}\text { NENGABULKAN } \\
\text { SEBAGIAN }\end{array}$ & MENAMBAH & Total \\
\hline 2014 & $6,70 \%$ & 77,288 & $14,92 \%$ & $0,04 \$$ & 2050 \\
\hline 2015 & $7,90 \%$ & $79,56 \%$ & $7,75 \%$ & $1,49 \%$ & 9253 \\
\hline 2016 & $7,92 \%$ & $77,63 \%$ & $14,42 \%$ & $0,03 \%$ & 9042 \\
\hline 2017 & $8,56 \%$ & $71,70 \%$ & $19,74 \%$ & $0,00 \%$ & 4230 \\
\hline Total & $7,68 \%$ & $7,30 \%$ & $13,27 \%$ & $0,47 \%$ & 30565 \\
\hline
\end{tabular}

Data tersebut menunjukkan bahwa kecil peluang wajib pajak untuk menang dalam sengketa pajak di tingkat keberatan. Permasalahan yang terjadi adalah banyak permohonan sengketa yang awalnya ditolak pada tingkat Keberatan tersebut ternyata dimenangkan oleh Pengadilan Pajak ketika wajib pajak mengajukan Banding.

Selain itu, kedudukan yang tidak setara antara fiskus dan wajib pajak saat proses keberatan menjadi salah satu sumber ketidakadilan. Posisi fiskus terlalu kuat pada proses Keberatan (Tampubolon, 2013). Ketidaksetaraan ini, menurut Tampubolon, diakibatkan oleh beberapa alasan sebagai berikut:

1) fiskus merangkap sebagai juri yang membuat keputusan;

2) fiskus adalah pihak yang diadukan/dituntut atas keputusan yang diterbitkannya

3) waktu fiskus untuk menyelesaikan sengketa lebih banyak daripada waktu yang disediakan kepada wajib pajak untuk membantah hasil penelitian fiscus;

4) pemeriksa dan peneliti keberatan memiliki tujuan yang sama yakni meningkatkan pendapatan pajak.

Pada kenyataannya, proses pembahasan tersebut seringkali bersifat formalitas semata, artinya proses tersebut dijalankan namun tidak memperhatikan substansi dari argumen wajib pajak (Pertiwi, 2015). Selain itu, adanya "keengganan" petugas pajak dalam mengabulkan keberatan sekalipun menurut bukti hukum, petugas penelaah keberatan harus mengabulkan permohonan keberatan (llyas dan Burton, 2008).

Menurut Adam Smith dalam Mark Skusen (2005), suatu sistem pemungutan pajak harus memenuhi 4 unsur agar efektif, yakni Asas Equality (keadilan), Asas Certainty (kepastian hukum), Asas Convenience of Payment (kenyamanan dalam pembayaran), dan Asas Economics (ekonomis). Salah satu yang ditekankan oleh Adam Smith adalah asas keadilan, dimana setiap pemungutan pajak yang dilakukan oleh negara harus sesuai dengan kemampuan dan penghasilan WP. Negara tidak boleh bertindak diskriminatif terhadap WP. Karena wajib pajaklah yang paling mengetahui kemampuan dan penghasilannya, maka pendapat wajib pajak harus dipertimbangkan secara objektif oleh fiskus dalam administrasi pemungutan pajak, baik pada saat konseling, pemeriksaan, maupun pada proses keberatan.

Berdasarkan data dari Tabel 1.2, tingkat kemenangan Direktorat Jenderal Pajak kecil apabila dibandingkan dengan tingkat kekalahan ketika berbicara sengketa pajak di tingkat Banding. Persentase kekalahan Direktorat Jenderal Pajak hampir 2 kali lipat persentase

Tabel 1.2. Data Putusan Pengadilan Pajak atas Banding

\begin{tabular}{|l|r|r|r|r|r|}
\hline $\begin{array}{c}\text { DJP } \\
\text { Menang/Kalah }\end{array}$ & $\mathbf{2 0 1 4}$ & $\mathbf{2 0 1 5}$ & $\mathbf{2 0 1 6}$ & $\mathbf{2 0 1 7}$ & $\mathbf{2 0 1 8}$ \\
\hline Menang & 2.076 & 2.487 & 2.669 & 2.034 & 1.883 \\
\hline Kalah & 2.296 & 2.369 & 2.970 & 3.042 & 2.807 \\
\hline Jumlah & 4.372 & 4.846 & 5.639 & 5.076 & 4.690 \\
\hline \% Menang & $47,48 \%$ & $51,32 \%$ & $47,33 \%$ & $40,07 \%$ & $40,15 \%$ \\
\hline
\end{tabular}


Pada kenyataannya, upaya keberatan yang seharusnya menjadi langkah awal wajib pajak dalam menyelesaikan sengketa pajak malah menjadi suatu hambatan bagi mereka. Meskipun mereka telah mempersiapkan aspek formal dan material pengajuan keberatan, Penelaah Keberatan cenderung lebih mempertahankan hasil SKP yang dikeluarkan pemeriksa pajak dan tidak mempertimbangkan argumentasi wajib pajak. Ketidakpuasan wajib pajak tercermin dari banyaknya wajib pajak yang mengajukan banding walaupun permohonan keberatannya telah ditolak, seperti yang tercermin dari Tabel 1.2.

Suatu strategi dan solusi dibutuhkan untuk mengurangi beberapa permasalahan di atas. Hal ini untuk meningkatkan kepuasan dan kepercayaan wajib pajak atas pelayanan administrasi yang ada di Direktorat Jenderal Pajak. Dengan adanya peningkatan kepuasan dan kepercayaan wajib pajak, biaya kepatuhan yang harus ditanggung oleh Wajib Pajak dan DJP bisa berkurang, sehingga wajib pajak dalam membayar dan melaporkan pajak dapat ditingkatkan.

Sebagai salah satu layanan unggulan di Direktorat Jenderal Pajak, kualitas pemrosesan Keberatan hendaknya tidak fokus pada ketepatan waktu saja, tetapi juga tepat sasaran dalam memberikan hasil telaahan yang adil dan objektif. Oleh Karena itu berdasarkan permasalahan dan uraian yang telah disebutkan di atas, penulis tertarik untuk meneliti lebih lanjut mengenai EVALUASI LEMBAGA KEBERATAN DALAM PENYELESAIAN SENGKETA PAJAK YANG ADIL DI DIREKTORAT JENDERAL PAJAK.

\section{KERANGKA TEORI DAN KERANGKA PEMIKIRAN}

\subsection{Pengertian Keadilan}

Dalam konsep keadilan pemungutan pajak yang dikemukakan oleh Adam Smith dalam Suady (2005), pembebanan pajak hendaknya seimbang dengan kemampuannya, yaitu seimbang dengan penghasilan yang dinikmatinya di bawah perlindungan pemerintah. Dalam hal equity ini tidak diperbolehkan suatu negara mengadakan diskriminasi di antara sesama Wajib Pajak.

Menurut Safa'at (2011), secara umum dikatakan bahwa orang yang tidak adil adalah orang yang tidak patuh terhadap hukum (unlawful, lawless) dan orang yang tidak fair (unfair), maka orang yang adil adalah orang yang patuh terhadap hukum (law-abiding) dan fair. Tujuan pembuatan hukum adalah untuk mencapai kemajuan kebahagiaan masyarakat. Rawls dalam Dwisvimiar (2011) berpendapat bahwa keadilan hanya dapat ditegakkan apabila negara melaksanakan asas keadilan, berupa setiap orang hendaknya memiliki hak yang sama untuk mendapatkan kebebasan dasar.

Dalam konsep keadilan dalam pemungutan pajak yang Adam Smith dalam Suandy (2005), pembebanan pajak hendaknya seimbang dengan kemampuannya, yaitu seimbang dengan penghasilan yang dinikmatinya di bawah perlindungan pemerintah. Dalam hal equity ini tidak diperbolehkan suatu negara mengadakan diskriminasi di antara sesama wajib pajak.

\subsection{Pengertian Pajak}

Menurut R.A. Seligman (1925), pajak adalah kontribusi wajib dari seseorang kepada pemerintah untuk membiayai pengeluaran yang terjadi untuk kepentingan bersama, tanpa merujuk pada manfaat khusus dianugerahkan.

Senada dengan pendapat Seligman, Adriani dalam Brotodihardjo (1981) mendifinisikan pajak adalah iuran rakyat kepada negara (yang dapat dipaksakan) yang terhutang oleh yang wajib membayarnya menurut peraturan-peraturan, dengan tidak mendapat prestasi kembali, yang secara langsung dapat ditunjuk, dan yang gunanya adalah membiayai pengeluaran-pengeluaran umum berhubung dengan tugas negara untuk menyelenggarakan pemerintahan.

Dalam Undang-undang Nomor 6 Tahun 1983 sebagaimana telah diubah terakhir dengan Undangundang Nomor 16 Tahun 2009, selanjutnya disebut Undang-undang KUP memberikan definisi bahwa pajak adalah kontribusi wajib kepada negara yang terutang oleh orang pribadi berdasarkan Undang-undang, dengan tidak mendapatkan imbalan secara langsung dan digunakan untuk keperluan negara bagi sebesarbesarnya kemakmuran rakyat.

\subsection{Konsep Sengketa Pajak}

Menurut Asmorowati (2011) sengketa pajak diawali adanya ketidaksamaan persepsi/pemahaman atau perbedaan pendapat salah satunya antara Wajib Pajak dan DJP atas penetapan pajak terutang untuk pajak-pajak pusat.

Sengketa pajak menurut Undang-undang Pengadilan Pajak adalah sengketa yang timbul dalam bidang perpajakan antara wajib pajak atau penanggung pajak dengan pejabat yang berwenang sebagai akibat dikeluarkannya keputusan yang dapat diajukan banding atau gugatan kepada pengadilan pajak berdasarkan peraturan perundang-undangan perpajakan, termasuk gugatan atau pelaksanaan penagihan berdasarkan Undang-undang Penagihan Pajak dengan Surat Paksa.

Menurut Barata dalam Siahaan (2012), perbedaan antara Wajib Pajak dengan Fiskus atas penetapan pajak disebabkan anatara lain:

1. Perbedaan persepsi dalam memahami ketentuan dalam perundang-undangan perpajakan;

2. Keterbatasan petugas dalam menginterprestasikan pola bisnis dan sistem akuntansi yang dianut Wajib Pajak;

3. Keterbatasan petugas dalam memahami peristilahan aktivitas bisnis dan penamaan akun dalam pembukuan karena Wajib Pajak tidak mengkomunikasikan dengan benar;

4. Ketidaktahuan dan ketidakmampuan Wajib Pajak dalam memahami peraturan perundang-undangan yang berlaku;

5. Ketidaktahuan dan ketidakmampuan Wajib Pajak dalam membedakan laporan keuangan komersial dengan laporan keuangan fiskal;

6. Perbedaan pendapat dalam pengakuan bukti pendukung/dokumen transaksi. 
Dalam menyelesaikan sengketa pajak ini Thuronyi (2016) memberikan beberapa alternatif penyelesaian sengketa pajak, antara lain: compromises, Disputes within the Taxation Authority, Tax Adjudications

Untuk mendapatkan perlindungan hukum bagi Wajib Pajak dalam menyelesaikan sengketa pajak, Saidi (2007) menyatakan bahwa upaya hukum yang telah disediakan oleh Undang-undang baik di luar maupun melalaui peradilan pajak. Berdasarkan Undang-undang KUP upaaya hukum yang dapat diajukan oleh Wajib Pajak, antara lain: keberatan (Pasal 25), pengurangan, penghapusan sanksi dan/atau pembatalan (Pasal 36) dan gugatan (Pasal 23).

\subsection{Konsep Keberatan}

Keberatan menurut Nurmantu dan Samudra (2003:626) adalah surat yang berisi pernyataan Wajib Pajak tentang ketidaksetujuannya terhadap jumlah yang menjadi dasar pengenaan pajak. Sedangkan Lyons (1996:6) menyatakan keberatan yaitu formal statement of disagreement with a tax assessment or a court decision notified to appropriate authority and initiating a formal process of reconsideration.

Widodo dan Djefris dalam Pertiwi (2015) menyatakan bahwa hak keberatan adalah hak setiap wajib pajak terhadap setiap putusan-putusan yang dibuat oleh otoritas pajak dan dapat diterapkan untuk hampir semua jenis keputusan yang diterbitkan oleh otoritas pajak, baik berupa pelaksanaan dan interprestasi hukum atau peraturan administrasi yang berdampak secara langsung terhadap wajib pajak.

The Organisation for Economic Co-operation and Development (OECD) menyatakan bahwa keberatan (appeal) adalah satu dari enam hak wajib pajak, yaitu the right of appeal yaitu:

The right of appeal against any decision of the tax authorities applies to all taxpayers and to almost all decisions made by the tax authorities, wether as regards the applications of the law or of administative rulings, provided the taxpayer is directly concerned.

Keputusan keberatan yang baik dan ideal bukanlah keputusan yang memenangkan Wajib Pajak atau memuaskan Direktorat Jenderal Pajak, tetapi keputusan yang adil dan objektif berdasar alat bukti yang sah sesuai peraturan perundang-undangan perpajakan (Gunadi, 2004).

Dalam Peraturan Menteri Keuangan Nomor 9/PMK.03/2013 memberikan beberapa pengertian terkait keberatan. Keberatan merupakan upaya administratif yang dapat dilakuakn Wajib Pajak atas ketetapan pajak yang diterbitkan DJP berdasarkan peraturan perundang-undnagan perpajakan yang berlaku. Surat Keberatan adalah surat yang diajukan WP kepada Dirjen Pajak mengenai keberatan terhadap suatu ketetaan atau pemotongan atau pemungutan pajak oleh pihak ketiga.

\subsection{Kerangka Pemikiran}

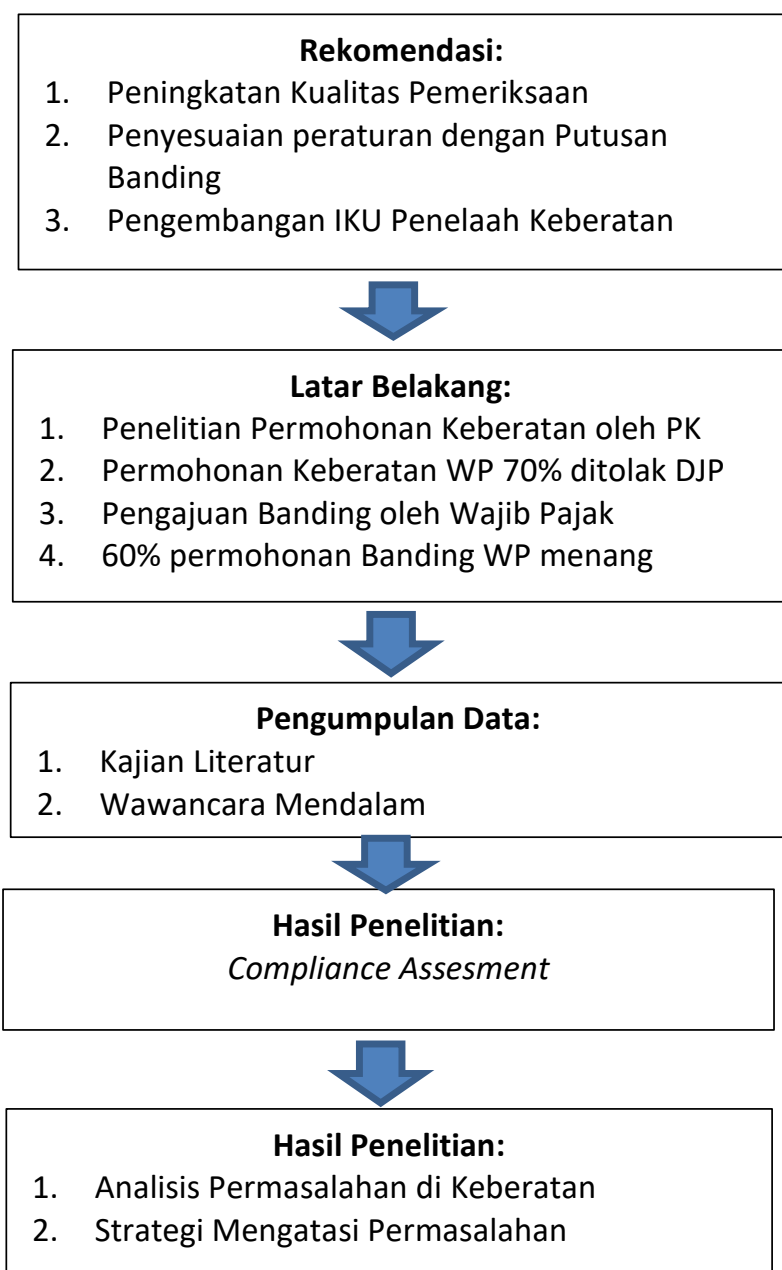




\section{HASIL PENELITIAN}

\subsection{Gambaran Umum Sistem Keberatan}

\subsubsection{Lembaga keberatan dalam sengketa pajak}

Amanat penyelesaian permohonan keberatan dinyatakan dalam Pasal 25 ayat (1) Undang-undang KUP. Latar Belakang dibuatnya sistem keberatan ini karena sistem pemungutan pajak di Indonesia menerapkan self assessment system.

Berdasarkan UU KUP tersebut Direktur Jenderal Pajak menerbitkan Keputusan Direktur Jenderal Pajak nomor KEP-106/PJ.11/1991 pada tahun 1991 tentang Pelimpahan Wewenang Direktur Jenderal Pajak kepada Para Pejabat di Lingungan Direktorat Jenderal Pajak, diantaranya menunjuk pihak yang berwenang mengeluarkan surat keputusan keberatan dibagi antara Direktur Jenderal Pajak, Kepala Kantor Wilayah DJP dan Kepala KPP dengan batasan atau arestasi masing-masing kewenagan.

Beberapa perubahan berikutnya tidak mengubah strukur pelimpahan wewenang atas penerbitan surat keputusan keberatan, hanya mengubah batasan arestasi yang menjadi wewenang masing-masing pemutus. Pada Tahun 2000, Pemerintah mengeluarkan UU Nomor 16 Tahun 2000 tentang Perubahan kedua atas UU No 6 Tahun 1983. Pasal 25 ayat (1) mengalami perubahan, wajib pajak dapat mengajukan keberatan atas suatu Surat Ketetapan Kurang Bayar, Surat Ketetapan Kurang Bayar Tambahan, Surat Ketetapan Pajak Lebih Bayar, Surat Ketetapan Pajak Nihil, dan pemotongan atau pemungutan oleh pihak ketiga. Walaupun demikian, Dirjen Pajak, kepala kantor wilayah dan kepala KPP masih dapat mengeluarkan surat putusan keberatan sesuai arestasi masing-masing. Hanya saja, pada 2002, seperti tertuang di lampiran Keputusan Dirjen Pajak nomor KEP-297/PJ/2002, batas arestasi untuk kepala KPP ditentukan oleh kantor wilayah atasannya.

Pada Tahun 2005, dengan dikeluarkannya Peraturan Dirjen Pajak Nomor PER-165/PJ/2005, pelimpahan wewenang mulai berubah meskipun baru diterapkan pada kantor wilayah DJP Jakarta Khusus, kanwil DJP Wajib Pajak Besar, dan kantor wilayah DJP yang menerapkan sistem administrasi perpajakan modern selain kanwil DJP Jakarta Khusus dan Wajib Pajak Besar. Pada kator pelayanan pajak di bawah dua kantor wilayah tersebut, kepala kantor pelayanan pajak tidak berwenang lagi mengeluarkan surat keputusan keberatan, tetapi diserahkan ke kepala kantor wilayah, dengan pengecualian atas keberatan sehubungan dengan ketetapan hasil pemeriksaan pejabat fungsional pemeriksa pajak Kantor Pusat DJP. Sampai pada titik ini, hanya kepala kantor wilayah dan Dirjen Pajak yang dapat mengeluarkan keputusan keberatan, sehingga kepala kantor pelayanan pajak tidak lagi berwenang untuk membatalkan SKP yang diterbitkannya sendiri melalui keberatan.

Pada tahun 2008, Undang-undang nomor 16 tahun 2008 terbit sebagai perubahan dari undangundang no 6 tahun 1983 tentang Ketentuan Umum dan Tatacara Perpajakan. Pasal mengenai Keberatan, yakni pasal 25, relatif sama dan tidak ada perubahan prosedur. Perubahan atas pihak yang berwenang memutus perkara keberatan yang terbaru pada tahun 2018 melalui Keputusan Dirjen Pajak nomor KEP146/PJ/2018. Pada keputusan tersebut, wewenang untuk menerbitkan keputusan atas keberatan yang diajukan Wajib Pajak, termasuk menerbitkan keputusan atas keberatan yang tidak diputuskan setelah melewati jangka waktu 12 (dua belas) bulan sepenuhnya diberikan pada kepala kantor wilayah, tanpa pengecualian apa pun. Permohonan keberatan tidk yang diproses oleh kantor pusat DJP, tetapi harus diputuskan di kantor wilayah.

\subsubsection{Mekanisme dan Tata Cara Keberatan}

Undang-undang nomor 6 tahun 1983 tentang Ketentuan Umum dan Tata Cara Perpajakan sttd Undang-undang Nomor 16 Tahun 2008 pasal 25 menyatakan dengan jelas bahwa permohonan keberatan yang dapat diproses adalah permohonan yang telah dianggap lengkap sesuai dengan peraturan, sehingga permohonan yang tidak memenuhi syarat tidak akan dipertimbangkan sebagai permohonan keberatan oleh Direktorat Jenderal Pajak.

Ketentuan mengenai pengajuan keberatan kemudian diatur lagi lebih rinci oleh menteri keuangan dalam PMK-194 Tahun 2007 tentang Tata Cara Pengajuan dan Penyelesaian Keberatan sebagai berikut:

a) diajukan secara tertulis dalam bahasa Indonesia;

b) mengemukakan jumlah pajak yang terutang atau jumlah pajak yang dipotong atau dipungut atau jumlah rugi menurut penghitungan Wajib Pajak dengan disertai alasan-alasan yang menjadi dasar penghitungan;

c) 1 (satu) surat keberatan diajukan hanya untuk 1 (satu) surat ketetapan pajak, untuk 1 (satu) pemotongan Pajak, atau untuk 1 (satu) pemungutan pajak.

d) Wajib Pajak telah melunasi pajak yang masih harus dibayar paling sedikit sejumlah yang telah disetujui Wajib Pajak dalam pembahasan akhir hasil pemeriksaan;

e) diajukan dalam jangka waktu 3 (tiga) bulan sejak tanggal dikirim surat ketetapan pajak atau sejak tanggal pemotongan atau pemungutan pajak oleh pihak ketiga kecuali Wajib Pajak dapat menunjukan bahwa jangka waktu tersebut tidak dapat dipenuhi karena keadaan di luar kekuasaan wajib Pajak (force majeur); dan

f) surat keberatan ditandatangani oleh Wajib Pajak, dan dalam hal surat keberatan ditandatangani oleh bukan Wajib Pajak, surat keberatan tersebut harus dilampiri dengan surat kuasa khusus.

\subsubsection{Prosedur penyelesaian keberatan.}

Prosedur penyelesaian keberatan diatur oleh menteri keuangan dalam PMK 194/PMK/03/2007 secara rinci. Namun UU KUP tahun 2007 mengatur secara garis besar prosedur penyelesaian keberatan 
yang harus dilaksanakan oleh Direktorat Jenderal Pajak dalam Pasal 26 sebagaimana berikut:

a) Direktur Jenderal Pajak dalam jangka waktu paling lama 12 (dua belas) bulan sejak tanggal surat keberatan diterima harus memberi keputusan atas keberatan yang diajukan.

b) Sebelum surat keputusan diterbitkan, Wajib Pajak dapat menyampaikan alasan tambahan atau penjelasan tertulis.

c) Keputusan Direktur Jenderal Pajak atas keberatan dapat berupa mengabulkan seluruhnya atau sebagian, menolak atau menambah besarnya jumlah pajak yang masih harus dibayar.

d) Dalam hal Wajib Pajak mengajukan keberatan atas surat ketetapan pajak sebagaimana dimaksud dalam Pasal 13 ayat (1) huruf b dan huruf d (UU KUP), Wajib Pajak yang bersangkutan harus dapat membuktikan ketidakbenaran ketetapan pajak tersebut.

e) Apabila jangka waktu sebagaimana dimaksud pada ayat (1) telah terlampaui dan Direktur Jenderal Pajak tidak memberi suatu keputusan, keberatan yang diajukan tersebut dianggap dikabulkan.

Prosedur penyelesaian keberatan diatur lagi dalam PMK-194/PMK/03/2007 tentang Tata Cara Pengajuan dan Penyelesaian Keberatan. Sebelum Direktur Jenderal Pajak menyampaikan Surat Pemberitahuan Untuk Hadir, Direktur Jenderal Pajak meminta keterangan, data, dan/atau informasi tambahan dari Wajib Pajak. Selain itu, Wajib Pajak menyampaikan alasan tambahan atau penjelasan tertulis untuk melengkapi dan/atau memperjelas surat keberatan yang telah disampaikan baik atas kehendak Wajib Pajak yang bersangkutan maupun dalam rangka memenuhi permintaan Direktur Jenderal Pajak. Setelah itu, Direktur Jenderal Pajak melakukan pemeriksaan untuk tujuan lain dalam rangka keberatan untuk mendapatkan data dan/atau informasi yang objektif yang dapat dijadikan dasar dalam mempertimbangkan keputusan keberatan.

Sebelum menerbitkan Surat Keputusan Keberatan, Direktur Jenderal Pajak harus menyampaikan Surat Pemberitahuan Untuk Hadir kepada Wajib Pajak guna memberi keterangan atau memperoleh penjelasan mengenai keberatannya. Dalam hal Wajib Pajak tidak hadir pada waktu yang ditentukan dalam Surat Pemberitahuan Untuk Hadir, proses keberatan tetap diselesaikan tanpa menunggu kehadiran Wajib Pajak. Pembukuan, catatan, data, informasi atau keterangan lain yang tidak diberikan pada saat pemeriksaan tidak dipertimbangkan dalam penyelesaian keberatan, kecuali pembukuan, catatan, data, informasi, atau keterangan lain tersebut berada di pihak ketiga dan belum diperoleh Wajib Pajak pada saat pemeriksaan.

\subsection{Evaluasi atas Implementasi Keberatan Dalam Penyelesaian Sengketa Pajak}

\subsubsection{Implementasi prosedur keberatan di Direktorat Jenderal Pajak.}

Suatu prosedur administrasi pemerintahan akan dikatakan tepat apabila mengikuti dasar hukum yang mengatur tentang prosedur itu sendiri. Sebagai lembaga eksekutif, Direktorat Jenderal Pajak bertugas melaksanakan undang-undang, termasuk undang-undang Ketentuan Umum dan Tata Cara Perpajakan (KUP).

Selama ini, Direktorat Jenderal Pajak melalui Penelaah Keberatan di bawah Seksi Pengurangan, Keberatan, dan Banding telah melakukan prosedur keberatan sesuai dengan ketentuan yang mengatur. Informan (N2) menyatakan bahwa penyelesaian sengketa keberatan sudah dilakukan sesuai dengan peraturan perundangundangan.

Indikator Kinerja Utama para Penelaah Keberatan di lingkungan DJP diukur berdasarkan kecepatan waktu pemrosesan Keberatan hingga keputusan. (N4) menyatakan bahwa target waktu setiap permohonan keberatan di aplikasi penilaian $e$ performance adalah 11 bulan. Hal ini untuk memastikan bahwa setiap permohonan keberatan diselesaikan tepat waktu oleh Penelaah Keberatan.

Selain jangka waktu, salah satu prosedur lain yang diamanahkan oleh Undang-undang KUP adalah pemenuhan hak wajib pajak untuk memperoleh kesempatan mendapat penjelasan dan memberikan keterangan terhadap permohonan Keberatannya. PMK 09/PMK.03/2013 sebagaimana terakhir telah diubah dengan PMK 202/PMK.03/2015 menyatakan pada pasal 15 bahwa "sebelum menerbitkan Surat Keputusan Keberatan, Direktur Jenderal Pajak meminta Wajib Pajak untuk hadir guna memberikan keterangan atau memperoleh penjelasan mengenai keberatan Wajib Pajak...". Selain itu, sebelum surat keputusan diterbitkan, wajib pajak masih dapat menyampaikan alasan tambahan atau penjelasan tertulis. Terkait dengan pembahasan sebelum closing, Informan (N1) menjelaskan bahwa: Wajib pajak itu diundang untuk pembahasan Keberatan apabila Penelaah Keberatan itu merasa perlu meminta keterangan atau memperoleh penjelasan. Tapi ketika wajib pajak misalnya diundang oleh Penelaah Keberatan untuk membicarakan pembahasan, maka wajib pajak wajib memberikan penjelasan atau keterangan-keterangan yang menurut Wajib Pajak itu bisa mempertahankan atau memohon agar sengketa wajib pajak dikabulkan oleh Penelaah Keberatan.

Sedangkan pada saat closing, wajib pajak wajib diundang oleh Penelaah Keberatan untuk membahas bersama hasil penelitian keberatan. Pembahasan dengan wajib pajak telah dilaksanakan dengan baik oleh setiap Penelaah Keberatan mengingat Surat Pemberitahuan Untuk Hadir (SPUH) dan Berita Acara Pembahasan wajib dilampirkan Penelaah Keberatan dalam laporan penelitiannya.

Dari pembahasan di atas, peneliti menyimpulkan bahwa mekanisme pemrosesan permohonan Keberatan telah memenuhi ketentuan tentang tata cara dan prosedur Keberatan. Prosedur 
tersebut dimulai sejak penelitian oleh Kantor Pelayanan Pajak saat permohonan disampaikan pada wajib pajak. Ketika wajib pajak memenuhi syarat formal yang diwajibkan oleh PMK 202/PMK.03/2015 tentang Perubahan Atas Peraturan Menteri Keuangan nomor PMK Nomor 9/PMK.03/2013 tentang Tata Cara Pengajuan dan Penyelesaian Keberatan, Kantor Pelayanan Pajak akan mengirimkan permohonan ke kantor wilayah.

\subsubsection{Permasalahan dalam proses Keberatan di Direktorat Jenderal Pajak}

Dalam Keberatan, pihak yang bersengketa adalah Wajib Pajak dengan Fiskus yang notabene berasal dari Direktorat Jenderal Pajak. Kedudukan yang tidak setara ini menjadi sumber ketidakadilan dalam proses Keberatan. Posisi fiskus terlalu kuat pada proses Keberatan (Tampubolon, 2013). Ketidaksetaraan ini, menurut Tampubolon, diakibatkan oleh beberapa alasan sebagai berikut:

1) fiskus merangkap sebagai juri yang membuat keputusan

2) fiskus adalah pihak yang diadukan/dituntut atas keputusan yang diterbitkannya

3) waktu fiskus untuk menyelesaikan sengketa lebih banyak daripada waktu yang disediakan kepada wajib pajak untuk membantah hasil penelitian fiskus

4) pemeriksa dan peneliti keberatan memiliki tujuan yang sama yakni meningkatkan pendapatan pajak.

Ketidakpuasan wajib pajak terhadap hasil keputusan keberatan yang mayoritas menolak seluruh atau hanya mengabulkan sebagian keberatan menjadi alasan untuk mengatakan bahwa proses Keberatan yang mereka mohonkan tidaklah adil. Pada tahun 2016, dari 9.042 berkas Keberatan yang dimasukkan oleh Wajib Pajak, hanya 7,92\% atau sekitar 716 permohonan yang dikabulkan seluruhnya. Sebanyak $19,74 \%$ atau sekitar 1.784 dikabulkan sebagian. Bahkan, sebanyak $77,63 \%$ atau sekitar 7.019 permohonan ditolak oleh Direktorat Jenderal Pajak. Hampir sama dengan tahun 2016, pada tahun 2017 (data per Oktober), permohonan Keberatan yang dikabulkan oleh Ditjen Pajak hanya $8,56 \%$ atau cuma sekitar 362 dari 4.230 berkas Keberatan. Sebanyak $19,74 \%$ atau sekitar 835 permohonan yang mendapat keputusan dikabulkan sebagian, dan ada $71,70 \%$ yang ditolak atau sekitar 3.032 permohonan.

Beberapa berpendapat bahwa ketidakadilan dalam proses Keberatan ini disebabkan oleh beberapa hal, yaitu:

1) adanya tekanan psikologis yang dirasakan oleh Penelaah Keberatan.

2) adanya "keengganan" petugas pajak dalam mengabulkan keberatan sekalipun menurut bukti hukum, petugas penelaah keberatan harus mengabulkan permohonan keberatan (Ilyas dan Burton, 2008). posisi Penelaah Keberatan yang masih berada di bawah payung Direktorat Jenderal Pajak secara struktural. Meskipun berkomitmen dalam hal objektivitas dan independensi, namun keterkaitan struktural tersebut membuat independence in appearance menjadi tidak ada.

3) masalah sumber daya manusia. Seorang Penelaah Keberatan diharuskan mereviu atau menelaah pekerjaan Fungsional Pemeriksa dalam tugasnya meneliti keberatan. Di DJP Penelaah Keberatan adalah jabatan pelaksana yang diberi tugas khusus, sedangkan Pemeriksa Pajak adalah jabatan fungsional. Perasaan negatif tersebut dapat berefek pada kurangnya koordinasi dan sinergi antara Pemeriksa dan Penelaah Keberatan, yang membuat penelitian atas Keberatan menjadi tidak objektif.

\subsubsection{Permasalahan terkait tekanan psikologis pada Penelaah Keberatan}

Ada anggapan bahwa ketika seorang Penelaah Keberatan mengabulkan suatu keberatan, itu artinya negara kehilangan uang sebesar jumlah pajak terutang yang dikabulkan. Persepsi tersebut dikuatkan lagi dengan anggapan bahwa menghilangkan keuangan negara berarti merugikan negara sehingga harus diminimalisasi melalui pengawasan ketat. Pengawasan tersebut adalah dalam bentuk audit atas hasil penelitian keberatan yang dikabulkan oleh auditor internal pemerintah seperti Badan Pemeriksa Keuangan dan Inspektorat Jenderal, dalam hal adalah Itjen Kementerian Keuangan. Setuju dengan hal ini, (N1) menyatakan di DJP, setelah proses Keberatan selesai, ada auditor eksternal yaitu BPK, BPKP dan Itjen yang memeriksa hasil Keberetan.

Senada dengan Informan (N1), Informan (N3) menjelaskan bahwa tekanan psikologis itu pasti ada, dalam hal ini adanya risiko akan diaudit oleh badan pengaudit. Ketakutan psikologis ini berpotensi membuat Penelaah Keberatan menjadi cenderung bermain aman dengan menolak permohonan Keberatan dan membiarkannya berlanjut ke Banding, dengan anggapan akan lebih baik jika hakim pengadilan pajak yang memutuskan. Adanya ketakutan itu karena selama ini, sasaran pemeriksaan oleh auditor internal pemerintah masih berfokus pada hasil keberatan yang mengabulkan dan mengabulkan sebagian. Lembaga auditor tidak memeriksa berkas keberatan yang ditolak DJP namun dimenangkan oleh hakim saat wajib pajak mengajukan Banding ke pengadilan pajak.

Hal itu menguatkan pendapat informan (N9) dari Komite Pengawas Perpajakan yang menjelaskan bahwa terdapat beberapa perbedaan tafsir antara Penelaah Keberatan dengan Badan Pemeriksa Keuangan (BPK). Di satu sisi, Penelaah Keberatan menafsirkan peraturan sesuai dengan makna yang disetujui bersama di Ditjen Pajak Di sisi lain, BPK terkadang memiliki tafsiran berbeda sehingga menjadikan hal itu temuan. Namun menanggapi hal ini, para penelaah keberatan di Direktorat Jenderal Pajak menganggap tekanan psikologis ini bukan sebagai hal yang berat dan dapat diatasi. Informan (N2) menjelaskan bahwa beliau sebagai Penelaah 
Keberatan tidak pernah takut dengan keberadaan auditor internal. Sebab sepanjang wajib pajak memang berhak untuk dikabulkan Keberatannya, maka akan dikabulkan oleh Penelaah Keberatan.

Dalam hal ini, Penelaah Keberatan dianggap diperlakukan tidak adil dengan pemeriksaan auditor internal yang hanya memeriksa berkas keberatan yang dikabulkan. Hal ini, menurut informaan (N1) dapat menimbulkan budaya "main aman" di kalangan Penelaah Keberatan.

Selain itu, permasalahan ini disetujui juga oleh praktisi pajak. Informan (N8) dari IG Tax menyatakan bahwa perlindungan terhadap petugas $\mathrm{PK}$ memang masih lemah dari sisi hukum, misalnya adanya Badan Pemeriksa Keuangan yang bisa meneliti setiap keputusan mereka jika dianggap merugikan keuangan negara. Selama petugas penelaah keberatan tidak diberikan jaminan perlindungan hukum, maka akan sulit bagi PK untuk membuat keputusan objektif karena putusan mereka dapat dituntut atau dikriminalkan baik sekarang maupun di masa yang akan datang.

Berdasarkan hasil wawancara dengan Komisi Pengawas Pajak (Komwasjak) Setjen Kemenkeu, Informan (N9) mengatakan bahwa ketakutan akan dikriminalisasi ini bermula dari terungkapnya kasus Gayus Tambunan. Berdasarkan survey yang dilakukan Komwasjak, ditemukan bahwa terhadap sekitar 140-an petugas, hampir semuanya merasa takut dikriminalisasi, namun hanya tiga saja yang pernah mengalaminya.

Dari pembahasan di atas, peneliti menyimpulkan bahwa persepsi mengenai tekanan psikologis karena ketakutan akan adanya pemeriksaan oleh auditor internal pemerintah hanya sedikit pengaruhnya terhadap objektivitas Penelaah Keberatan. Ketakutan tersebut dapat diatasi atau diminimalisasi dengan kerja sama tim, penguatan bukti dan telaahan, serta supervisi yang ketat dari atasan sebagai jaminan bahwa mereka juga terlibat dalam penyelesaian kasus Keberatan.

\subsubsection{Permasalahan terkait struktur organisasi Keberatan yang tidak independen.}

Dalam dunia audit, independensi adalah suatu sikap dan prinsip fundamental yang sangat diperlukan seorang auditor. Karena itu beberapa ahli mendefinisikan independensi dalam lingkup audit lebih terperinci lagi. Antle dalam Mayangsari (2003) mendefinisikan independensi adalah sehubungan antara akuntan dan kliennya yang mempunyai sifat sedemikian rupa sehingga temuan dan laporan yang diberikan auditor hanya dipengaruhi oleh bukti-bukti yang ditemukan dan dikumpulkan sesuai dengan aturan atau prinsip-prinsip profesionalnya.

Mulyadi (2008), mendefinisikan independensi sebagai kejujuran dalam diri auditor dalam mempertimbangkan fakta dan adanya pertimbangan yang objektif tidak memihak dalam diri auditor dalam merumuskan dan menyatakan pendapatnya. Arens (2006) membagi dua jenis independensi dalam dua jenis, yakni independensi dalam fakta (independence in fact) dan independensi dalam penampilan (independence in appearance). Independensi dalam fakta dicapai apabila auditor benar-benar mampu mempertahankan sikap yang tidak bias sepanjang audit. Sedangkan independensi dalam penampilan adalah hasil dari interpretasi lain atas independensi ini. Misalnya, secara fakta auditor internal dapat melakukan audit yang benar-benar tidak bias terhadap sebuah divisi, dimana kepala divisi tersebut adalah saudara kandung auditor internal yang bersangkutan. Walaupun dapat bekerja secara tidak bias, namun sebagian besar fungsi audit telah hilang karena adanya hubungan istimewa auditor internal dengan auditee.

Dalam hubungannya dengan Keberatan, Penelaah Keberatan akan kembali memeriksa dan menguji Laporan Hasil Pemeriksaan yang dikeluarkan oleh fungsional pemeriksa pajak, yang adalah rekannya sesama fiskus. Sengketa antara fungsional pemeriksa penerbit Surat Ketetapan Pajak dan wajib pajak diselesaikan oleh lembaga Keberatan yang berada di kantor wilayah yang membawahi kantor pelayanan pajak. Pada titik Keberatan, kesetaraan hubungan antara wajib pajak dan fiskus memiliki kesenjangan yang paling tinggi dari seluruh proses dan praktek perpajakan di Indonesia (Tampubolon, 2013). Karena itu, seberapa objektif pun seorang Penelaah Keberatan dalam bekerja, tetap saja itu hanya akan memperkuat independence in fact, namun independence in appearance-nya tidak terpenuhi.

Dalam implementasinya, Ditjen Pajak wajib melakukan pembahasan dengan Wajib Pajak pada saat closing. Pembahasan dan permintaan keterangan dan bukti kepada wajib pajak juga dilakukan pada saat proses penelitian. Keterangan dan bukti yang disampaikan oleh wajib pajak dapat berupa keterangan/ bukti yang menguatkan argumen wajib pajak, maupun melemahkannya. Semakin baik bukti yang diserahkan oleh wajib Pajak, maka semakin besar kemungkinan hal itu akan dipertimbangkan Penelaah Keberatan dalam mengabulkan permohonan Keberatannya. Setiap keterangan dan penjelasan wajib pajak pasti dipertimbangkan. Bukti dan dokumen yang tidak dipertimbangkan hanyalah bukti/dokumen yang tidak diberikan wajib pajak ke pemeriksa pada saat proses pemeriksaan sebelumnya. Hal itu sesuai dengan amanah UU KUP pasal 26A ayat (4):

Wajib Pajak yang mengungkapkan pembukuan, catatan, data, informasi, atau keterangan lain dalam proses keberatan yang tidak diberikan pada saat pemeriksaan, selain data dan informasi yang pada saat pemeriksaan belum diperoleh Wajib Pajak dari pihak ketiga, pembukuan, catatan, data, informasi, atau keterangan lain dimaksud tidak dipertimbangkan dalam penyelesaian keberatannya.

Komitmen Ditjen Pajak dalam melayani permohonan Keberatan secara professional dan objektif masih terhambat bentuk struktural lembaga yang masih rentan dilanda konflik kepentingan. Masalah independensi menjadi alasan kecurigaan wajib pajak untuk berprasangka bahwa Keberatan mereka diproses dengan berat sebelah. Lembaga 
Keberatan merupakan bagian dari Lembaga Peradilan Pajak, sehingga kita harus mengetahui apakah lembaga keberatan merupakan lembaga peradilan pajak secara murni atau tidak. Saidi (2007) menguraikan empat tolok ukur unsur-unsur pajak peradilan pajak murni:

1) pajak sebagai suatu perselisihan hukum yang konkret;

2) perselisihan hukum yang konkret itu diterapkan hukum pajak yang bersifat abstrak dan mengikat secara hukum

3) sekurang-kurangnya dua pihak yang bersengketa atau berperkara;

4) adanya pihak yang berwenang memeriksa dan memutus dan tidak terlibat sebagai pihak yang bersengketa (berperkara) yang berasal dari aparatur peradilan pajak.

Di Direktorat Jenderal Pajak, yang berwenang memutus Keberatan adalah kepala kantor wilayah yang notabene masih membawahi pihak yang bersengketa, yakni penerbit Surat Ketetapan Pajak, kepala kantor pelayanan pajak. Bahkan dapat juga dikatakan bahwa Keberatan adalah sengketa pajak antara wajib pajak dengan Direktorat Jenderal Pajak, dan yang menyelesaikan sengketa pajak di tahap Keberatan adalah Direktorat Jenderal Pajak. Sejalan dengan itu, Marbun (1997) menjelaskan bahwa model penyelesaian sengketa pajak melalui proses Keberatan merupakan penyelesaian melalui upaya administratif yaitu penyelesaian sengketa di mana penyelesaiannya masih termasuk pihak yang berperkara yaitu Fiskus (proses Keberatan) dalam penyelesaian sengketa dan dimaksudkan untuk memudahkan pencari keadilan memperoleh keadilan dan memperoleh perlindungan hukum baik bagi administrasi sendiri maupun bagi warga. Peneliti bertindak selaku hakim yang memutuskan dimana posisi Peneliti bukan merupakan hakim yang mandiri melainkan merupakan bagian dari administrasi sehingga dikategorikan sebagai Peradilan Administrasi Tidak Murni (Soemitro, 1991).

Permasalahan independensi memang menjadi dilema bagi Penelaah Keberatan mengingat posisi Penelaah Keberatan yang masih berada di bawah naungan Direktorat Jenderal Pajak. Namun Penelaah Keberatan dalam hal ini selalu berusaha menjaga pemeriksaan dilakukan sesuai dengan prosedur perundangundangan dan selalu menekankan agar pemeriksaan dilakukan secara netral dan tidak memihak baik kepada DJP ataupun kepada Wajib Pajak. Permasalahan independensi ini menjadi penting. Karena walau bagaimana pun, proses Keberatan adalah suatu bentuk peradilan administrasi, yang secara konsep berbeda dengan Pengadilan Pajak. Keberatan yang menganut hukum administrasi negara.

Dari pembahasan di atas, Peneliti menarik kesimpulan bahwa lembaga Keberatan memang tidak akan bisa menerapkan asas keadilan secara murni dan tidak akan independen secara kelembagaan. Hal ini karena lembaga Keberatan dibentuk dalam ranah administrasi pajak yang masih merupakan otoritas dari
Direktorat Jenderal Pajak dengan mengikuti prinsip hukum administrasi pajak. Karena itu proses Keberatan, dilihat dari ranah administrasi perpajakan, memang tidak dapat dirancang untuk independen sepenuhnya.

\subsubsection{Permasalahan terkait Sumber Daya Manusia}

Seorang Penelaah Keberatan diharuskan mereviu atau menelaah pekerjaan Fungsional Pemeriksa dalam tugasnya meneliti keberatan. Dalam Ditjen Pajak, Penelaah Keberatan adalah jabatan pelaksana yang diberi tugas khusus, sedangkan Pemeriksa Pajak adalah jabatan fungsional.

Pemeriksaan yang dilakukan oleh fungsional pemeriksa merupakan awal dari adanya sengketa pajak. Uji kepatuhan pada saat pemeriksaanlah yang sebenarnya membuktikan apakah wajib pajak patuh atau tidak, bukan di Keberatan atau Banding. Karena itu, Direktorat Jenderal Pajak memperkuat posisi fungsional pemeriksa di jajarannya dengan mengadakan pendidikan dan latihan untuk meningkatkan kompetensi pemeriksa. Selain itu, pengangkatan fungsional juga rutin dilakukan demi menambah formasi pemeriksa pajak. Pemeriksa pajak, dalam melakukan pemeriksaan, bekerja dalam tim yang dipimpin oleh seorang ketua tim dan diawasi oleh supervisor. Supervisor dan ketua tim, di banyak kantor pelayanan pajak, adalah fungsional yang paling senior dan telah memiliki golongan dan pangkat yang tinggi. Jabatan mereka juga membuat mereka terspesialisasi selama karir mereka di fungsional, yang artinya mereka telah memiliki banyak pengalaman dalam memeriksa.

Berbeda dengan fungsional pemeriksa, Penelaah Keberatan adalah jabatan pelaksana khusus yang setara dengan Account Representative (AR), dan dibawahi oleh seorang kepala seksi. Biasanya seseorang ditugaskan sebagai Penelaah Keberatan setelah sebelumnya telah bertugas menjadi AR.

Misalkan dalam suatu kasus Keberatan, seorang Penelaah Keberatan meneliti dan mereviu ulang Laporan Hasil Pemeriksaan yang dikerjakan oleh pemeriksa. Penelaah Keberatan akan memanggil fungsional pemeriksa yang mengerjakan LHP tersebut dan meminta penjelasannya perihal materi yang dimohonkan Keberatan oleh wajib pajak. Begitu juga dengan wajib pajak, akan dipanggil oleh Penelaah Keberatan untuk permintaan keterangan. Dalam hal ini, karena menganggap fungsional lebih pintar dan lebih berpengalaman, Penelaah Keberatan akan cenderung lebih menyetujui pendapat pemeriksa pajak, apalagi kalau pemeriksa pajaknya sudah sangat cakap. Menurut Penelaah Keberatan yang pernah Peneliti ajak diskusi, ada beberapa fungsional pemeriksa yang tidak menerima kalau pekerjaannya dikoreksi oleh Penelaah Keberatan karena telah merasa benar.

Berdasarkan Laporan Tahunan DJP 2015, menurut data yang Peneliti dapatkan dari Komisi Pengawas Pajak, SDM yang menangani sengketa pajak (penelaah keberatan) berjumlah 761 orang (atau 
sekitar dua persen dari jumlah keseluruhan pegawai di DJP) yang tersebar di seluruh Kanwil di Indonesia. Secara kuantitatif, jumlah SDM ini masih memadai untuk menangani sengketa pajak di tingkat administratif, namun melihat adanya potensi peningkatan sengketa pajak, maka perlu adanya antisipasi atau terobosan baru dalam penanganan sengketa.

Permasalahan utama dalam manajemen SDM khususnya bagi penelaah keberatan adalah belum dilaksanakannya manajemen secara optimal untuk meningkatkan profesionalisme dan kinerja pegawai. Berdasarkan hasil pengawasan dari Inspektorat Jenderal, diketahui bahwa lebih dari $70 \%$ penelaah keberatan belum mengikuti diklat yang dibutuhkan untuk mencapai kecukupan kompetensi pegawai. Selain itu belum ada pengaturan pola pengembangan (rekrutmen dan mutasi) yang setara antara penelaah keberatan, AR dan pejabat fungsional pemeriksa yang dapat meningkatkan kapasitas penelaah keberatan yang memadai sehingga penelaah keberatan yang mempunyai latar belakang sebagai fungsional pemeriksa jumlahnya sangat minim.

\subsubsection{Tinjauan atas efektivitas Keberatan dan urgensinya dalam penyelesaian sengketa pajak.}

Selama 4 tahun terakhir, keputusan yang menolak keberatan selalu berada di atas angka $70 \%$ per tahunnya. Sedangkan keputusan untuk mengabulkan sebagian permohonan Keberatan WP berada di posisi tertinggi kedua, yakni 13,27\% secara total 4 tahun. Gejala ini memperlihatkan betapa kecilnya peluang wajib pajak untuk menang dalam sengketa pajak di tingkat keberatan. Permasalahan yang terjadi adalah banyak permohonan sengketa yang awalnya ditolak pada tingkat Keberatan tersebut ternyata dimenangkan oleh Pengadilan Pajak ketika wajib pajak mengajukan Banding. Tabel 1.2. menyajikan data amar putusan Banding oleh Pengadilan Pajak.

Dari Tabel IV.1 dapat dilihat tingkat kemenangan DJP kecil apabila dibandingkan dengan tingkat kekalahan ketika berbicara sengketa pajak di tingkat Banding. Persentase kekalahan DJP hampir 2 kali lipat persentase kemenangannya. Jika angka ini dijadikan indikator, hal ini menjadikan Keberatan belum efektif dalam menyaring sengketa pajak di tingkat administrasi dan menyelesaikannya, karena masih berlanjut ke Pengadilan Pajak.

Ketika wajib pajak mengajukan Banding atas Surat Keputusan Keberatan, tidak serta merta mengindikasikan bahwa Penelaah Keberatan tidak adil. Ketika penelitian, enam informan dari Direktorat Jenderal Pajak ditanyakan pertanyaan berikut: Lembaga keberatan adalah pemutus sengketa. Suatu pemutus sengketa akan dianggap adil apabila dia dapat memutus sengketa (Keberatan) tanpa menimbulkan/berlanjut ke sengketa baru (Banding). Apakah bapak setuju jika indikator efektivitas
Keberatan dinilai dari situ? Hasilnya, lima informan menjawab tidak setuju atas indikator tersebut, sedangkan satu menjawab seharusnya idealnya seperti itu. Alasan mereka tidak setuju adalah karena Banding itu murni hak wajib pajak yang dilindungi undangundang. Undang-undang KUP pasal 27 ayat (1) mengatakan Wajib Pajak dapat mengajukan permohonan banding hanya kepada badan peradilan pajak atas Surat Keputusan Keberatan. Tidak disebutkan di situ bahwa Banding dapat diajukan hanya ketika wajib pajak merasa tidak puas atau diperlakukan tidak adil. Tidak peduli Wajib Pajak sudah diperlakukan adil atau tidak, mereka akan tetap mengajukan Banding ketika mereka diharuskan membayar pajak yang nilainya besar. Sebagaimana yang disampaikan oleh Informan (N6) pada saat wawancara, Ketidakpuasan WP dalam hal keberatan bukan menjadi indikator. Ketidakpuasan WP dalam keberatan dibuktikan dengan banding, itu tidak masalah, karena memang sudah diatur dalam proses undang-undang. Artinya WP tersebut tidak bisa langsung banding, harus mengikuti prosedur hukum.

Hal berbeda disampaikan oleh Informan (N8) dari kantor konsultan pajak IG Tax. Wahyudi menjelaskan bahwa sebenarnya wajib pajak lebih menginginkan sengketa pajaknya selesai di tingkat Keberatan dan tidak berlanjut ke Banding. Hal ini karena upaya Banding membutuhkan usaha, materi, dan waktu yang lebih besar. Pembahasan sidang Banding di Pengadilan Pajak membutuhkan waktu 12 bulan, yang dapat diperpanjang sampai 3 bulan. Sedangkan putusan Banding tidak diatur jangka waktu keluarnya dan murni wewenang hakim. Karena itu, ada beban moral tambahan pada wajib pajak ketika tidak ada kepastian hukum bagi mereka. Pendapat ini sejalan dengan pendapat Penelaah Keberatan, Ajat yang mengatakan: "Dengan demikian menurut saya memang idealnya permohonan keberatan itu memang berakhir di keberatan saja, tidak perlu lanjut ke banding apalagi ke Peninjauan Kembali."

Selain banyaknya Keputusan Hasil Keberatan yang diajukan Banding, hasil dari Banding itu sendiri juga oleh beberapa pihak dijadikan indikator efektivitas lembaga Keberatan. Dari data yang didapat dari Komisi Pengawas Perpajakan, salah satu indikator yang mereka jadikan indikasi penanganan sengketa pajak masih belum optimal adalah tingkat kemenangan DJP atas sengketa banding dan gugatan di Pengadilan Pajak dalam tiga tahun terakhir (2014 s.d. 2016) yang secara rata-rata (dengan amar putusan tolak, tambah, mengabulkan sebagian, tidak dapat diterima) adalah sekitar 29,5\%. Hal ini senada dengan penjelasan dari Staf Ahli Menteri Keuangan Bidang Pengawasan Pajak, Puspita (N10), bahwa tingkat kekalahan DJP di Pengadilan Pajak dapat dijadikan indikator tidak efektifnya lembaga Keberatan. Menurut Wahyudi dari IG Tax (N8), alasan seringnya Wajib Pajak maju ke Banding adalah karena mereka merasa putusan di keberatan belum adil. Jadi lebih sering bukan karena nilai yang mungkin pada dasarnya wajib pajak sanggup untuk bayar, namun lebih kepada ketidakadilan yang mereka dapatkan. Apalagi kasus 
yang berulang dimana koreksi dari PK akan terus menerus berulang padahal hasilnya akan sama pada akhirnya.

Dengan permasalahan yang ada di praktik Keberatan selama ini, Peneliti kemudian meneliti apakah sistem penyelesaian sengketa pajak dengan proses Keberatan masih dibutuhkan oleh sistem perpajakan kita atau sebaiknya langsung ke Banding. Terhadap tujuh informan, peneliti kemudian menanyakan pertanyaan berikut: "Apakah menurut Bapak sistem Keberatan untuk menyelesaikan sengketa pajak di DJP masih dibutuhkan? Ataukah lebih baik langsung ke Banding?" Hasilnya, ketujuh informan tersebut sepakat menjawab bahwa Keberatan masih dibutuhkan, baik bagi Ditjen Pajak, maupun bagi Wajib Pajak. Salah satu informan, Denny (N1) menjelaskan dalam wawancara: Karena kalau dari segi aspek hukum di upaya hukum, dari mulai produk hukum, kemudian ada namanya proses keberatan sebelum ke banding. Nah itu tidak bisa kalau ada produk hukum, terus ada sengketa, langsung ke banding. Itu tidak bisa. Harus ada proses Jadi tidak bisa semata-mata langsung banding. Sebelum itu ada namanya proses keberatan. Jadi keberatan harus tetap ada sebelum ke banding. Masih tetap diperlukan.

Dari pembahasan di atas, Peneliti mengambil kesimpulan bahwa efektivitas Keberatan tidak dapat diukur hanya dari jumlah kemenangan Wajib Pajak di Banding. Selisih antara jumlah permohonan Keberatan yang ditolak oleh Ditjen Pajak dengan jumlah kekalahan Ditjen Pajak yang cukup besar juga disebabkan oleh faktor-faktor lain yang di luar kendali Penelaah Keberatan. Faktor-faktor tersebut adalah regulasi yang digunakan sebagai acuan dan tingkat keadilan hakim yang berbeda dengan Penelaah Keberatan. Penelaah Keberatan hanya mengacu pada regulasi yang dikeluarkan pemerintah sedangkan hakim pengadilan pajak berwenang menggunakan dasar hukum lain, atau bahkan tidak menggunakan dasar hukum pajak dalam pertimbangan keputusannya. Selain itu, batasan keadilan yang dipakai oleh Penelaah Keberatan dan Hakim juga berbeda. Penelaah Keberatan akan dianggap adil apabila telah memutuskan sesuai dengan aturan, sedangkan Hakim berwenang menggunakan nurani dan keyakinannya akan keadilan dalam memutuskan perkara. Meskipun demikian, dengan permasalahanpermasalahan yang ada, sistem Keberatan masih dibutuhkan dalam administrasi perpajakan Indonesia.

\subsection{Strategi Mengatasi Permasalahan Lembaga Keberatan}

\subsubsection{Strategi mengatasi permasalahan tekanan psikologis.}

Tekanan psikologis yang dialami oleh Penelaah Keberatan dapat menghilangkan objektivitasnya dalam meneliti Keberatan. Tekanan dari kepala kantor wilayah terkait penerimaan pajak dan ketakutan akan dikriminalisasi menjadi beban bagi Penelaah Keberatan.
Sebagai solusi atas tekanan psikologis ini, dibutuhkan kerja sama tim untuk menemukan dasar yang kuat apabila permohonan tersebut akan dikabulkan. Informan (N4) mencontohkan dengan penjelasan mengenai koreksi atas pajak masukan yang tidak ada fakturnya. Ada kemungkinan pada saat prosedur pemeriksaan di kantor pelayanan pajak, pajak masukan akan dikoreksi karena keterbatasan waktu pemeriksaan. Namun pada saat penelitian keberatan, pajak masukan diuji lagi melalui uji arus kas dan arus barang sehingga dapat dibuktikan dengan kuat. Penelaah Keberatan yang lain, Informan (N3) menjelaskan solusi mengatasi ketakutan psikologis terhadap auditor sebagai berikut. Akan tetapi sebenarnya hal itu bisa diatasi sepanjang kita melakukan tugas kita sesuai dengan prosedur. Tambahan lagi tekanan psikologi itu dapat diminimalisir jika atasan kita melakukan supervisi dan koordinasi disertai jaminan bahwa mereka juga ikut terlibat dalam penyelesaian kasus keberatan. Penelaah Keberatan juga harus diberikan kepastian bahwa mereka tidak akan dipidanakan ketika bekerja sesuai aturan. Pimpinan organisasi harus turun langsung untuk memberi jaminan keamanan bagi para Penelaah Keberatan.

Selain itu, koordinasi harus dilakukan oleh Ditjen Pajak dengan para auditor pemerintah, seperti Badan Pemeriksa Keuangan dan Inspektorat Jenderal. Koordinasi ini diperlukan untuk mengubah persepsi selama ini yang menganggap bahwa keputusan mengabulkan permohonan Keberatan merupakan keputusan yang merugikan keuangan negara. Ketakutan Penelaah Keberatan dipicu oleh para auditor pemerintah yang menjadikan permohonan yang dikabulkan menjadi temuan mereka sehingga harus diperiksa intensif. Sependapat dengan itu, Informan (N1) menjelaskan dalam wawancaranya sebagai berikut: Auditor eksternal sebaiknya tidak semata-mata mengaudit atau memeriksa untuk amar putusan yang dikabulkan saja. Sehingga teman-teman itu benarbenar teliti juga, tidak asal tolak. Kalau misalnya kita asal tolak, padahal menurut BPK ini harus dikabulkan, itu juga harus diperiksa. Ketika memeriksa, auditor pemerintah harus mempertimbangkan dengan baik alasan Penelaah Keberatan mengabulkan permohonan Keberatan. Acuan dan sudut pandang yang dipakai oleh auditor juga sebaiknya sama dengan yang dipakai Penelaah Keberatan. Yang kadang terjadi adalah selama ini adanya perbedaan tafsir akan peraturan pajak antara Penelaah Keberatan dengan auditor. Dengan adanya perlindungan hukum dari pimpinan organisasi dan pengawasan dan komunikasi yang optimal dari auditor pemerintah, permasalahan tekanan psikologis ini dapat dikurangi sehingga tidak mengganggu objektivitas Penelaah Keberatan.

Dari pembahasan di atas, Peneliti menyimpulkan bahwa untuk mengatasi permasalahan Keberatan terkait tekanan psikologis, Penelaah Keberatan diberikan jaminan perlindungan hukum ketika menyelesaikan kasus Keberatan sesuai prosedur dan objektif, terutama ketika hasil keputusannya adalah mengabulkan. Diperlukan juga komunikasi yang 
baik dengan lembaga auditor pemerintah sehingga dapat dicapai kesepahaman mengenai pengawasan yang optimal dan adil.

\subsubsection{Strategi mengatasi permasalahan terkait struktur organisasi Keberatan yang tidak independen.}

Struktur organisasi lembaga Keberatan yang masih berada di bawah pimpinan kepala kantor wilayah dianggap tidak independen karena adanya target penerimaan pajak yang dibebankan pada kantor wilayah. Konflik kepentingan kepala kantor wilayah timbul ketika dia akan memutuskan Surat Keputusan Keberatan. Karena itu dibutuhkan struktur organisasi baru yang lebih independen daripada struktur organisasi yang sekarang. Informan (N1) menjelaskan dalam wawancaranya sebagai berikut: Kalau kita menganut unsur keadilan, kita seharusnya tidak terbebani dengan masalah penerimaan. Makanya dari segi itu, apakah lembaga atau unit keberatan yang sekarang ada di kanwil itu harus keluar dari DJP atau keluar dari Kanwil, di bawah unit tersendiri dan tidak menanggung target penerimaan pajak. Reorganisasi struktur untuk mengatasi independensi ini dilakukan dengan membentuk lembaga Keberatan di luar kepala kantor wilayah. Bidang Keberatan, Banding, dan Pengurangan di kantor wilayah akan dipisah dan tidak dibawah pimpinan kepala kantor wilayah lagi. Lembaga tersebut akan dipimpin oleh seorang pejabat eselon II.

Mengenai desain lembaga Keberatan yang baru, Informan (N6), Kepala Seksi Desain Organisasi Ditjen Pajak menjelaskan dalam wawancara sebagai berikut: Jadi dia di luar kantor wilayah, di seluruh Indonesia dibentuk lima unit yang mengakomodasi seluruh Indonesia. Kenapa 5 unit? Sebenarnya beban/permohonan WP bervariatif, di setiap kanwil tidak selalu sama. Ada yang banyak, ada yang sedikit. Jadi itu untuk efisiensi juga. Efisiensi yang dimaksud adalah dalam administrasi Keberatan di kantor wilayah. Selain untuk meningkatkan independensi, pemisahan lembaga Keberatan ini juga untuk membangun spesialisasi dan efisiensi.

Selain rancangan pemisahan bidang Keberatan, Banding, dan Pengurangan dari kantor wilayah, terdapat alternatif lain perbaikan struktur organisasi dengan mencontoh struktur administrasi sengketa pajak negara lain, yakni Australia dan Jepang.

Proses penyelesaian sengketa pajak di Australia sebenarnya hampir sama dengan di Indonesia. Australian Tax Office (ATO) menyediakan upaya Keberatan (Objection) atas ketetapan yang tidak disetujui wajib pajak. Hanya saja, ATO memfasilitasi mediasi bagi wajib pajak dengan nilai bisnis yang kecil (small business) dengan menggunakan In-house Facilitation. Dalam fasilitasi ini, wajib pajak akan bertemu dengan pegawai ATO dengan dimediasi oleh fasilitator yang berasal dari ATO. Fasilitator ini merupakan fasilitator profesional dan tidak ada keterkaitannya dengan keputusan ketetapan sebelumnya. Mereka bersikap netral dan tidak memihak.

Di Jepang, sengketa pajak di tingkat sebelum pengadilan ditangani oleh National Tax Tribunal (NTT) yang berada di bawah National Tax Agency (NTA). NTT menangani upaya Keberatan (request for reconsideration) atas ketetapan NTA. Meskipun secara struktur berada di bawah NTA, namun NTT adalah organisasi yang terpisah wewenang dan fungsinya dari administrasi pengumpulan pajak nasional. Pada tahun 1984, bentuk NTT berubah dari "lembaga afiliasi" menjadi "lembaga khusus". NTT berada di bawah supervisi Presiden dan ketuanya ditunjuk oleh NTT Commissioner berdasarkan persetujuan Menteri Keuangan. Majelis hakim di NTT dipilih bukan dari internal NTA, namun dari hakim pengadilan dan jaksa yang memiliki pengetahuan dan pengalaman di perpajakan. Hal ini membuat NTT benar-benar independen dalam memutuskan suatu perkara.

Dari pembahasan di atas, Peneliti menyimpulkan bahwa perubahan struktur kelembagaan dibutuhkan untuk meningkatkan independensi dan objektivitas Penelaah Keberatan. Struktur lembaga Keberatan dapat berupa unit terpisah dari kantor wilayah untuk memisahkan kepentingan kantor wilayah dengan lembaga Keberatan seperti di Jepang. Untuk peningkatan efisiensi, proses penyelesaian sengketa Pajak juga dapat diubah sistemnya dengan menerapkan mekanisme mediasi seperti di negara Australia.

\subsubsection{Strategi mengatasi permasalahan terkait sumber daya manusia.}

Untuk mengatasi perbedaan pangkat dan golongan antara Penelaah Keberatan dan Pemeriksa Pajak, DJP mewacanakan akan adanya fungsionalisasi Penelaah Keberatan. Karena Penelaah Keberatan juga berada pada ranah penegakan hukum, maka statusnya diharapkan sama dengan Pemeriksa dan Penyidik. Selain itu juga untuk spesialisasi keahlian fiskus dalam meneliti Keberatan.

Sedangkan untuk meningkatkan kompetensi dan keahlian Penelaah Keberatan, dapat dilakukan dengan pemberian pendidikan dan latihan (diklat) teknis terkait penanganan Keberatan. Setiap Penelaah Keberatan yang akan diangkat seharusnya telah mendapatkan materi dasar mengenai penanganan Keberatan. Diklat selanjutnya dapat diadakan untuk meningkatkan keahlian Penelaah Keberatan.

\section{KESIMPULAN DAN SARAN}

Berdasarkan analisis dan pembahasan, penulis menarik beberapa kesimpulan sebagai berikut:

1. Secara formal implementasi pemrosesan permohonan keberatan telah sesuai dengan tata cara dan prosedur keberatan yang berlaku. Terdapat beberapa permasalahan antara lain: adanya tekanan psikologis para Penelaah Keberatan, struktur organisasi yang tidak independen yang mengakibatkan tidak objektif 
dalam memproses keberatan dan permasalahan manajemen SDM khususnya bagi penelaah keberatan dan beban kerja yang tidak merata.

2. Dalam upaya peningkatan kualitas proses keberatan terdapat beberapa strategi untuk mengatasi masalah yang ada, yaitu: penelaah keberatan diberikan jaminan perlindungan hukum, perubahan struktur kelembagaan lembaga keberatan untuk meningkatkan independensi dan objektivitas penelaah keberatan dan terkait kompetensi sumber daya manusia dapat dilakukan dengan menjadikan penelaah keberatan sebagai fungsional dan diberikan pendidikan dan pelatihan yang terstruktur dan berkelanjutan.

Selajutnya berdasarkan beberapa kesimpulan tersbeut di atas, penulis mengajukan beberapa saran sebagai berikut:

1. Objek Keberatan adalah Surat Ketetapan Pajak yang diterbitkan Pemeriksa sehingga pemeriksaan merupakan hulu dari timbulnya sengketa Keberatan. Terkait dengan hal ini, kualitas pemeriksaan perlu ditingkatkan khususnya mengenai pembuktian pada saat penetapan SKP.

2. Indonesia merupakan negara dengan sistem hukum kontinental dan tidak menjadikan yurisprudensi sebagai sumber hukum utama. Namun demikian, untuk mencegah kasus Keberatan yang berulang di kemudian hari karena peraturan pajak, perlu adanya penyesuaian peraturan perpajakan dengan keputusan Banding yang memenangkan wajib pajak.

3. Selama ini Indikator Kinerja Utama Penelaah Keberatan hanya ketepatan waktu penyelesaian Keberatan. Perlu ditinjau lagi indikator-indikator lain yang relevan untuk meningkatkan kualitas pekerjaan Penelaah Keberatan.

\section{IMPLIKASI DAN KETERBATASAN}

Penulis menyadari masih ada keterbatasan dalam penelitian ini, yakni:

1. Pembahasan sengketa pajak dalam penyelesaian keberatan sangat luas, dalam penelitian ini peneliti tidak membahas sengketa pajak secara teknis terkait pemeriksaan sampai dengan permohonan banding.

2. Sumber pembahasan diperoleh hanya berasal dari wawancara narasumber dan studi literatur. Peneliti tidak melakukan observasi secara langsung proses penyelesaian keberatan di Kantor Wilayah DJP.

3. Penelitian tidak membahas contoh kasus Surat Keputusan Keberatan yang dapat menambah gambaran materi sengketa pajak secara nyata dikarenakan keterbatasan waktu penelitian.

\section{DAFTAR PUSTAKA}

\section{Buku dengan Pengarang Tunggal:}

Atep Adya. 1998. Memahami Pengadilan PajakMeminimalisasi dan Menghindari Sengketa Pajak dan Bea Cukai. Jakarta. PT Elex Media Komputindo

Brotodiharjo, R. Santoso (2013). Pengantar IImu Hukum. Penerbit Refika Aditama.

Cresswell, John W. 2016. Research Design: Pendekatan Metode Kualitatif, Kuantitatif, dan Campuran. Edisi Ke-4. Yogyakarta: Pustaka Pelajar.

Djamali, Abdul. 2009, Pengantar Hukum Indonesia, Raja Grafindo Persada, Jakarta.

Gunadi. 2004. Bunga Rampai Pemeriksaan Penyidikan dan Penagihan Pajak. Jakarta: MUC Publishing

Gunadi. 2017. Panduan Komprehensif Ketentuan Umum Perpajakan (KUP). Jakarta: MUC Publishing

Kurnia Rahayu, Siti. (2017). Perpajakan (Konsep dan Aspek Formal. Penerbit Rekayasa Sains,

Lyons, Susan M. 1996. International Tax Glossary. International Buerau of Fiscal Documentation.

Marbun, S.F. 1997. Peradilan Administrasi Negara dan Upaya Administratif di Indonesia. Yogyakarta: Liberty.

Mulyadi.2008. Auditing. Jakarta : Salemba Empat Musgrave, Richard. 1989. Public Finance in Theory and Practice. New York: McGraw-Hill Book Company.

Pandiangan, Liberti (2014). Aministrasi Perpajakan. Penerbit Erlangga. Jakarta.

Saidi, Muhammad Djafar. 2007. Pembaharuan Hukum Pajak. Jakarta: PT. Raja Grafindo Persada.

Seligman, R A. 1925. Essays on Taxation. New York: Macmilan.

Skusen Mark. 2005. Sang Maestro Teori-teori Ekonomi Modern. Jakarta: Prenada. Soemahamidjaja,

Soemitro, Rochmat. 1991. Pajak Ditinjau dari Segi Hukum. Bandung: PT. Eresco.

Soeparman. 1964. Pajak Berdasarkan Asas Gotong Royong. Jakarta: Universitas Indonesia.

Soemitro, Rochmat. 1997. Asas dan Dasar Perpajakan 2. Bandung: PT Eresco.

Sugiyono. 2014. Metode Penelitian Kuantitatif, Kualitatif, dan R\&D. Bandung: Alfabeta, CV.

Suandy, Erly. 2002. Perpajakan. Jakarta: Salemba Empat.

Suandy, Erly. (2011). Hukum Pajak. Penerbit Salemba Empat. Jakarta.

Sundoro. 2004. Studi Kasus Banding Pengadilan Pajak: Buku Satu Tata Cara dan Dasar Hukum. Jakarta: Semar Publishing.

Tampubolon, Karianton. 2013. Praktek, Gugatan, dan Kasus-Kasus Pemeriksaan Pajak. Jakarta: PT.Indeks. Thuronyi, Victor. 1996. Tax Law Design and Drafting Volume 1. International Monetary Fund. 


\section{Buku dengan dua pengarang:}

Arens, Alvin A dkk. 2006. Auditing dan Jasa Assurance, Jilid 1. Jakarta: Erlangga.

B. Ilyas, WIrawan., \& Burton, Richard. (2013).Hukum Pajak: Teori, Analisis, dan Perkembangannya. Penerbit Salemba Empat. Jakarta.

Devano, Sony dan Siti Kurnia Rahayu. 2006. Perpajakan: Konsep, Teori dan Isu. Jakarta: Prenada Media Group.

Nurmantu, Safri dan Samudra. 2003. Dasar-Dasar Perpajakan: Edisi Kedua. Jakarta: Pusat Penerbitan Universitas Terbuka.7 Pertiwi,

Purwito, Ali dan Rukiah Komariah. 2010. Pengadilan Pajak: Proses Keberatan, Banding, Gugatan dan Peninjauan Kembali Edisi Revisi 3. Jakarta: FH UI Press.

Tran-Nam, Binh and Michael Walpole. 2016. Tax disputes, litigation costs and access to tax justice. The University of New South Wales Australia. eJournal of Tax Research Volume 14, Number 2: 319-336.

\section{Peraturan}

Indonesia. Undang-Undang Pengadilan Pajak. UndangUndang No. 14 Tahun 2002 tentang Pengadilan Pajak.

Undang-Undang Ketentuan Umum dan Tata Cara Perpajakan. UndangUndang No.6/1983 tentang Ketentuan Umum dan Tata Cara Perpajakan sebagaimana telah beberapa kali diubah terakhir dengan Undang-Undang No. $16 / 2009$.

Undang-Undang Pajak Pertambahan Nilai dan PPnBM. Undang-Undang No.8/1983 tentang Pajak Pertambahan Nilai Barang dan Jasa dan Pajak Penjualan Atas Barang Mewah sebagaimana telah beberapa kali diubah terakhir dengan UndangUndang No. 42/2009.

Kementerian Keuangan. Peraturan Menteri Keuangan Republik Indonesia Nomor 184/PMK.03/2015 tentang Perubahan Atas Peraturan Menteri Keuangan Nomor 17/PMK.03/2013 tentang Tata Cara Pemeriksaan. Jakarta: Kementerian Keuangan, 2015

Peraturan Menteri Keuangan Republik Indonesia Nomor 17/PMK.03/2013 tentang Tata Cara Pemeriksaan. Jakarta: Kementerian Keuangan, 2013.

Peraturan Menteri Keuangan Republik Indonesia Nomor 202/PMK.03/2015 tentang Perubahan Atas Peraturan Menteri Keuangan Nomor 9/PMK.03/2013 tentang Tata Cara Pengajuan dan Penyelesaian Keberatan. Jakarta:

Kementerian Keuangan, 2015. Peraturan Menteri Keuangan Republik Indonesia Nomor 9/PMK.03/2013 tentang Tata Cara Pengajuan dan Penyelesaian Keberatan. Jakarta: Kementerian Keuangan, 2013.

Direktorat Jenderal Pajak. Peraturan Direktur Jenderal Pajak Nomor PER-23/PJ/2013 tentang
Standar Pemeriksaan. Jakarta: Direktorat Jenderal Pajak, 2013.

\section{Website:}

Australian Tax Office.

https://www.ato.gov.au/General/Dispute-orobject-to-an-ATOdecision/Object-to-an-ATOdecision/ (diakses 15 Desember 2017)

Darussalam, Danny. Kedudukan Pengadilan Pajak di Berbagai Negara. http://www.ortax.org/ortax/?mod=issue\&page $=$ show $\&$ id $=41 \&$ list $=\& q=\& h / m=6$

\section{Karya IImiah:}

Avriyani, Ririn. 2013. Analisis Efektivitas Penyelesaian Keberatan Sesuai Dengan Program Layanan Unggulan (Studi Kasus Kanwil DJP Jakarta Pusat). Skripsi: Universitas Indonesia Barata,

Fitri Dianing. 2015. Analisis Penyelesaian Keberatan Pajak Ditinjau dari Prinsip Good Governance pada Kantor Wilayah DJP Jakarta Selatan. Skripsi: Universitas Indonesia.

Mayangsari, Sekar. 2003. Analisis Pengaruh Independensi, Kualitas Audit, serta Mekanisme Corporate Governance Terhadap Integritas Laporan Keuangan. Simposium Nasional Akuntansi VI. Surabaya, 16 - 17 Oktober 2003

Serbo, Machmud. 2005. Efektifikasi Keberatan dan Banding Dalam Upaya Penyelesaian Pajak. Tesis: Universitas Indonesia.

Siahaan, Rony Ricardo. 2012. Kajian Penyebab Permohonan Banding Wajib Pajak Dimenangkan di Pengadilan Pajak dan Upaya-Upaya DJP Untuk Meminimalisirnya. Tesis: Universitas Indonesia.

Artikel Jurnal dengan No. Halaman Bersambung: Asmorowati, Meiti. 2011. Sengketa Keberatan Dibandingkan Dengan Sengketa Pengadilan Pajak Berdasarkan Peraturan Yang Berlaku. Jurnal Wawasan Hukum, Volume 25 No 02.

Ispriyarso, Budi. 2019. Administrative Law \& Governance Journal Volume 2 Issue 2, Juni 2019 